\title{
ОСНОВНІ АСПЕКТИ ОРГАНІЗАЦІЇ ДІАГНОСТИКИ ТА РЕАБІЛІТАЦЇ̈ ДІТЕЙ ІЗ ПСИХОТРАВМАТИЧНИМ ДОСВІДОМ
}

\author{
Панченко О. А., Кабанцева А. В.
}

\section{ВСТУП}

Сучасні діти живуть в епоху соціальних потрясінь, глобалізаційних змін і високої інформаційної напруги, що зумовлює надзвичайно інтенсивний ритм життя і постійний вплив стресових факторів на дитячу психіку. Особливо це спостерігається в середовищі, досвіду життя в якому українці ще тільки набувають. Це політична та соціальна нестабільності на Сході України, воєнні дії, внутрішнє переселення, перезавантаження багатьох сфер держави (реформування), криза економічної системи, наслідки якої відбиваються на житті дорослих і дітей.

За таких обставин у макросоціумі кожної сім'ї діти потрапляють у несприятливі соціально-психологічні умови, переживають одразу декілька травмуючих подій: від негативної інформації до страху бойових дій, від переїзду та розлучення з близькими до втрати рідних або друзів. Посилюються тривога та страх за своє життя та життя близьких, які залишилися у зоні бойових дій. Усе це призводить до ускладнення адаптації, порушення повноцінного зростання й розвитку.

Слід відзначити, що кожна травмуюча ситуація несе не тільки загрозу порушення внутрішньої гармонії, а й мінімізацію прихованих можливостей відновлення і зростання, тому ця проблема ставить перед науковцями та практиками завдання щодо забезпечення максимально відповідних умов для повноцінного розвитку дітей, а у разі набуття психотравматичного досвіду - сприяння максимально швидкому їх відновленню.

Таким чином, актуальним питанням $є$ організація своєчасної діагностики та реабілітації дітей з емоційними порушеннями щодо попередження складних психічних, психосоматичних розладів, підвищення життєздатності дитини (життєстійкості) та створення оптимальних умов для максимального розкриття потенційних можливостей кожної дитини, у т. ч. під час негативних впливів соціального оточення. 


\section{1. Діагностика та наслідки психоемоційних порушень серед дітей}

Під час погіршення соціально-психологічних умов життя, особливо в періоди локальних воєн і збройних конфліктів, що часто виникають у різних регіонах світу (Азербайджані, Афганістані, Беслані, Вірменії, Ізраїлі, Ірані, Іраку, Сирії, Сомалі, Судані, Україні, Чечні), дітям доводиться переносити дуже важкі випробування, зокрема на психоемоційному рівні.

Війна - це травматична епідемія. Йдеться не тільки про тілесні травми, а насамперед про душевні страждання, наслідки яких можуть бути такими ж руйнівними, як і наслідки ран фізичних. Спектр цих наслідків широкий: від відносно легких порушень адаптації до клінічно виражених посттравматичних стресових розладів і тяжких депресій ${ }^{1}$. Ці зміни можуть перейти у відтерміновані наслідки посттравматичних стресових розладів і мати негативний вплив на подальше життя дитини. Отже, необхідно звернути пильну увагу на те, як емоції відображаються на фізичному та психічному стані дітей і які наслідки цих переживань.

Як зазначає К.А. Ідрісов, уже виросло ціле покоління дітей, котрі не бачили нормального, щасливого дитинства. Замість цього вони ховалися від війни, виживали в таборах біженців, стояли в чергах за гуманітарною допомогою ${ }^{2}$.

Багато дослідників указують, що в дітей, які зазнали психологічної травми, спостерігається постійне відтворення пережитого в різних формах: у яскравих страхітливих візуалізаціях (флешбеках), у багаторазових іграх на тему травматичної події, у кошмарних сновидіннях. Діти чекають і бояться реального повторення цієї події ${ }^{3}$.

У родині, котра пережила психологічну травму, часто спостерігається суперечливе поєднання побутового симбіозу 3 емоційною відстороненістю. Дитина постійно перебуває поряд із батьками, проте емоційне спілкування між ними різко послаблене. Можна сказати, що вони поруч, але не разом

Через збройний конфлікт на Сході України більше двох мільйонів осіб були переміщені всередині країни, а багато сімей утратили свої

1 Кузьмінов В.Н., Шестопалова Л.Ф. Розлади адаптації серед цивільного населення, що пережило бойові дії, через місяць після їхнього припинення. Український вісник психоневрологї. 2014. Т. 22. Вип. 3. С. 5-12.

2 Больные души чеченских детей. URL: http://www.watchdog.cz/?show=000000000002-000001-000110-000045\&lang=2 (дата звернення: 08.12.2020).

3 Terr L.C. Childhood traumas: an outline and overview. American Journal of Psychiatry. 1991. 10-20. P. 148.

4 Венгер А.Л., Морозова Е.И. Психологическая помощь детям и подросткам после Бесланской трагедии. Владимир : Транзит-ИКС, 2009. 170 с. 
доходи ${ }^{5}$. За даними Дитячого фонду ООН (ЮНІСЕФ), ця надзвичайна ситуація - криза, що залишила невиправний слід у житті тисяч дітей. Статус дитини, яка постраждала внаслідок воєнних дій і збройних конфліктів, мають понад 33 тисячі дітей ${ }^{6}$.

Під час воєнного конфлікту на Сході України з метою підвищення національної безпеки в межах зони проведення антитерористичної операції були створені контрольні пропускні пункти в’їзду-виїзду, де несли службу військові в повному обмундируванні зі зброєю.

Нам неодноразово траплялися випадки, коли по допомогу до психологів зверталися батьки дітей дошкільного віку зі скаргами на те, що за незмінної сприятливої атмосфери в сім’ї їхні діти останнім часом ставали більш вразливими до різких звуків або дій, мали пригнічений або засмучений емоційний стан, який нічим не пояснювався, спостерігалися м'язова напруженість і скутість у тілі. Навіть були випадки із проявами нічного енурезу. У дорослих складалася думка, ніби їхні діти постійно перебувають у стані очікування. Але в очікуванні чого? Ці діти не були під обстрілами, вони не бачили страхіть, які скоює війна, у іхній присутності не велися розмови дорослих про війну, загибель і страждання жертв бойових дій.

Під час роботи із психологом встановлено, що причиною цього був саме дитячий переляк під час перетинання пункту пропуску. Дітей налякав (вразив) зовнішній вид військовослужбовця, котрий мав зброю. Він виконував свої обов'язки: перевіряв документи водія, пасажирів, оглядав транспортний засіб, де перебували діти зі своїми батьками, які їхали до своїх близьких, родичів, друзів, а хтось уперше у своєму житті вирушив на відпочинок. Діти мали яскраві мрії на близьке майбутнє, що в одну мить стало сірим і небезпечним. Лише тривала професійна робота психологів, лікарів, педагогів змогла відновити психоемоційний стан цих дітей і повернути їх до нормального життя.

Отже, емоційний стан дітей Донбасу становить особливий науковий i практичний інтерес, оскільки дослідження цього кола проблем відбувається вперше. Фахівці не мають достатньої кількості інформації щодо повного вирішення наявних проблем i удосконалення комплексної допомоги 3 метою відновлення, формування психічно здорової особистості дитини.

У рамках науково-дослідної роботи (НДР) за замовленням Міністерства охорони здоров'я України «Розробка системи медико-

${ }^{5}$ Number of Ukrainian children needing aid nearly doubles to 1 million over the past year - UNICEF. URL: https://www.unicef.org/media/media_94886.html (дата звернення: 27.09.2019)

${ }^{6}$ Статус дитини, яка постраждала внаслідок воєнних дій та збройних конфліктів, на сьогодні мають понад 33 тисячі дітей. URL: https://www.ukrinform.ua/rubricsociety/2791124-v-ukraini-ponad-33-tisaci-ditej-maut-status-postrazdalih-unaslidokvoennih-dij.html (дата звернення: 6.12.2020) 
психологічної допомоги дітям та підліткам, що перебувають у зоні проведення антитерористичної операції» (номер державної реєстрації 0116U004162), що виконувалася на базі Д3 «Науково-практичний медичний реабілітаційно-діагностичний центр MO3 України», проводилися динамічні дослідження психоемоційного стану дітей і підлітків Донецької області. На основі отриманих результатів розроблено алгоритм виявлення дітей, котрі зазнали психотравмуючого досвіду, технологію надання високоефективної медико-психологічної реабілітаційної допомоги.

Ураховуючи той факт, що діти більшу частину свого часу проводять в освітньому закладі, педагог $є$ однією 3 осіб, після батьків, яка максимально близька до дитини. Саме педагог (вихователь чи вчитель) може першим визначити ознаки емоційних порушень і обговорити ці моменти з батьками, залучити психолога освітнього закладу.

Наочними ознаками, характерними для дитини, що має емоційне напруження або постраждала від психотравмуючих подій, $\epsilon^{7}$ :

- замкненість;

- страх або, навпаки, демонстрація повної відсутності страху, ризикована, зухвала поведінка;

- емоційна лабільність;

- неврівноважена поведінка;

- агресивність, напади люті, схильність до руйнації, нищення та насильства;

- уповільнене мовлення, нездатність до навчання, відсутність знань, відомих дітям відповідного віку (наприклад, невміння читати, писати та рахувати);

- уникання однолітків, бажання спілкуватися та гратися зі значно молодшими дітьми;

- занижена самооцінка;

- тривожність;

- швидка стомлюваність, знижена спроможність до концентрації уваги;

- наявність стресопохідних розладів психіки, психосоматичних хвороб.

У випадках, коли педагог помітив, що дитина потерпає від психотравмуючих подій або перебувала за таких умов, він має повідомити про це практичного психолога, адміністрацію освітнього закладу. Із метою виявлення психотравмуючого впливу на дитину фахівець (практичний психолог закладу освіти) повинен застосувати такі методи збору інформації:

${ }^{7}$ Проблеми розвитку та корекції емоційної сфери молодшого школяра / упоряд. О.А. Атимасова. Харків : Вид-во «Ранок», 2010. 176 с. 
- бесіду з дитиною;

- опитування батьків, піклувальників, педагогів, які безпосередньо працюють із дитиною;

- дослідження історії життя, здоров'я дитини, документації, інших джерел інформації;

- діагностику емоційного стану.

Під час виконання науково-дослідних робіт свою ефективність застосування у діагностичній роботі показали психодіагностичні методики, що увійшли у психодіагностичні комплекси для дітей дошкільного віку й окремо для дітей шкільного (підліткового) віку.

Групу респондентів - дітей дошкільного віку у віці 5-7 років склали 1308 осіб, групу шкільного віку у віці 10-14 років - 408 осіб.

Психодіагностичний комплекс для дітей дошкільного віку: «Паровозик» (С.В. Вєлієва), «Неіснуюча тварина» (М.З. Друкаревіч), «Кактус» М.О. Панфілової, опитувальник страхів А.І. Захарова, тест «Драбина» (В.Г. Щур), «Малюнок сім’ї» (Г.Т. Хоментаускас).

Психодіагностичний комплекс для дітей шкільного віку: Дитячий опитувальник неврозів (ДОН), методика діагностики рівня і характеру агресії Басса - Даркі, проективна методика «Намалюй свій страх».

Загалом серед дітей дошкільного віку встановлено страхи різного характеру $(61,2 \%)$, наявність тривожності, занепокоєності, хвилювання $(53,2 \%)$, прояви агресивності $(36,7 \%)$, низької самооцінки $(18,4 \%)$.

Встановлено, що більше половини респондентів мають страх фізичних ушкоджень i страх війни. Також високі відсотки діагностовано серед соціальних, медичних, просторових, тваринних страхів і страху темряви (табл. 1).

Таблиця 1

Наявні страхи дітей Сходу України

\begin{tabular}{|c|c|c|}
\hline Види страхів & Кількість респондентів & \% \\
\hline Страх фізичних ушкоджень & 704 & 53,8 \\
\hline Страх війни & 644 & 51,5 \\
\hline Медичні страхи & 575 & 45,1 \\
\hline Соціальні страхи & 564 & 45,1 \\
\hline Страхи темряви & 577 & 46,2 \\
\hline Страх тварин & 442 & 35,4 \\
\hline Відкриті простори & 361 & 31,3 \\
\hline
\end{tabular}

Порівняння наявності страхів за роками показало, що показники страху війни та фізичних ушкоджень залишалися високими упродовж усього часу дослідження. Найбільші відсотки страхів діагностовано у 2014 i 2017 pp. Тенденція до максимального зниження страхів спостерігалася у 2018 р. (рис. 1). 


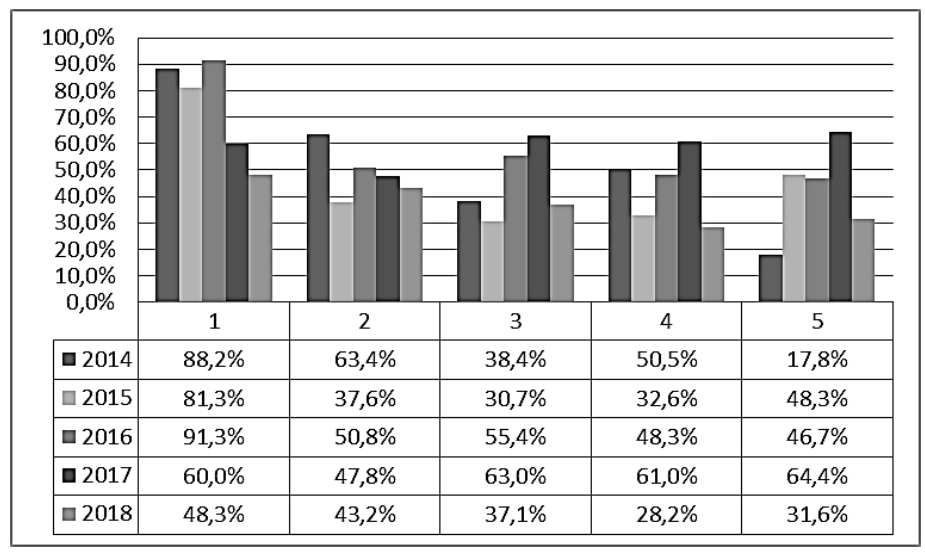

Рис. 1. Типи страхів дітей 5-7 років у період 2014-2018 pp.

Примітка: 1 - війна; 2 - фізичні ушкодження; 3 - темрява; 4-медичні; 5 - соиіальні

Медичні страхи та страх темряви відповідають віковим особливостям зазначеної групи респондентів. Страхи війни та фізичних ушкоджень $є$ придбаними у тому середовищі, де зростають діти.

Систематичне вивчення показало високі відсотки наявності тривожності у респондентів і певні зміни упродовж усього часу дослідження. У 2014 р. кількість дітей, які мали тривожність, становила 54,4\%; у 2015 p. - 73,1\%; 2016 p. - 41,9\%; 2017 p. - 75,6\%; 2018 p. $51,2 \%$. Агресивність у психоемоційному стані дітей також мала місце протягом усього періоду дослідження: 2014 р. - 34,2\%; 2015 р. - 39,3\%; 2016 p. $-39,4 \% ; 2017$ p. $-54,4 \% ; 2018$ p. $-23,1 \%$.

У $57,4 \%$ дітей, що взяли участь у дослідженні, встановлено почуття самотності, незахищеності у своїх сім'ях. Поряд із цим аналіз дитячобатьківських відносин встановив, що сприятливу сімейну атмосферу мають 966 осіб (72,6\%), несприятливу внутрішньо-сімейну ситуацію $342(27,3 \%)$.

Встановлено, що несприятлива сімейна атмосфера формує у дітей почуття самотності та незахищеності, яке впливає на самооцінку, сприймання себе і своїх можливостей. Статистично доведено, що чим більше проявів агресії з боку дорослих, тим вищий рівень проявів власної агресивності у дітей $(\mathrm{r}=0,302 ; \mathrm{p} \leq 0,01)$, тим частіше вони не почуваються частиною своєї сім'ї $(\mathrm{r}=0,435 ; \mathrm{p} \leq 0,05)$. Зневага батька породжує у дітей потребу у додатковій увазі $(\mathrm{r}=0,305 ; \mathrm{p} \leq 0,01)$, а зневага матері викликає розвиток тривожності $(\mathrm{r}=0,322 ; \mathrm{p} \leq 0,01)$ та невротичних станів $(\mathrm{r}=0,331 ; \mathrm{p} \leq 0,01)$. Отже, навіть за сприятливого сімейного клімату дитина може не відчувати того рівня 
безпеки і затишку, яких потребує ії індивідуально-психологічний або психоемоційний стан. Слід підкреслити, що для дитини перших років життя (дошкільного періоду) сім'я відіграє першорядну і незаперечну роль. Особливої актуальності цей факт набуває за несприятливих соціальних умов, таких як: нагнітання соціальної нестабільності в суспільстві через інформаційні атаки засобів масової інформації, проведення антитерористичної операції й об'єднаної операції збройних сил на території держави, фізичні, моральні, матеріальні втрати як наслідки останніх. Тому будь-яка емоція (i, тим більше, та, яка виникає за умов стресу в дітей за бойових умов) виникає під впливом інформаційної переробки батьками тих подій, що відбуваються у навколишньому середовищі.

Вивчення самооцінки показало, що 660 дітей $(51,8 \%)$ мали середній рівень (адекватний) рівень самооцінки, 455 (32,4\%) - високий, $186(11,9 \%)$ - низький. Тільки у 2018 р. почали переважати високий $(69,9 \%)$ і адекватний $(27,1 \%)$ рівні самооцінки, низького майже не було (3\%). У свою чергу, упродовж 2014-2017 рр. переважали середній і низькій рівні самооцінки у рівних відсотках, високого рівня самооцінки майже не визначалося, що є неприродним для цієї вікової категорії дітей, оскільки для них нормою виступає саме підвищена самооцінка.

За результатами діагностики серед дітей підліткового віку встановлено соціальні страхи, страхи фізичних ушкоджень і страх війни (рис. 2).

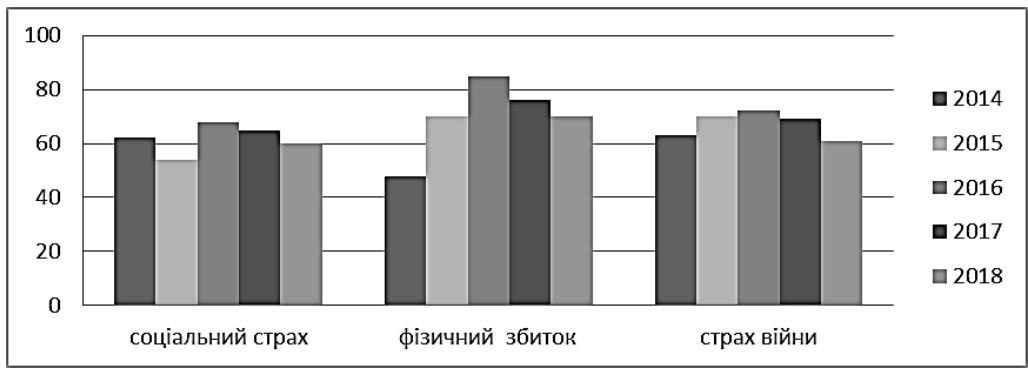

Рис. 2. Типи страхів дітей 10-14 років у період 2014-2018 pp.

Також підліткам притаманні невротичні прояви, серед яких: депресія, астенія, вегетативні розлади, порушення сну, агресія (рис. 3).

Наявність виявлених психоемоційних порушень у дітей і підлітків може спровокувати деформацію психоемоційного стану з подальшим розвитком складних психологічних і психічних проблем, таких як контракція комунікативних навичок, розвиток неврозів, затяжного психотравматичного стресового розладу. Тому ця проблема вимагає 
нагального комплексного вирішення у розбудові комплексної медикопсихологічної допомоги, що складатиметься із лікувальнореабілітаційного, корекційного, рекреаційного напрямів для попередження й усунення чинників психічних розладів у останніх.

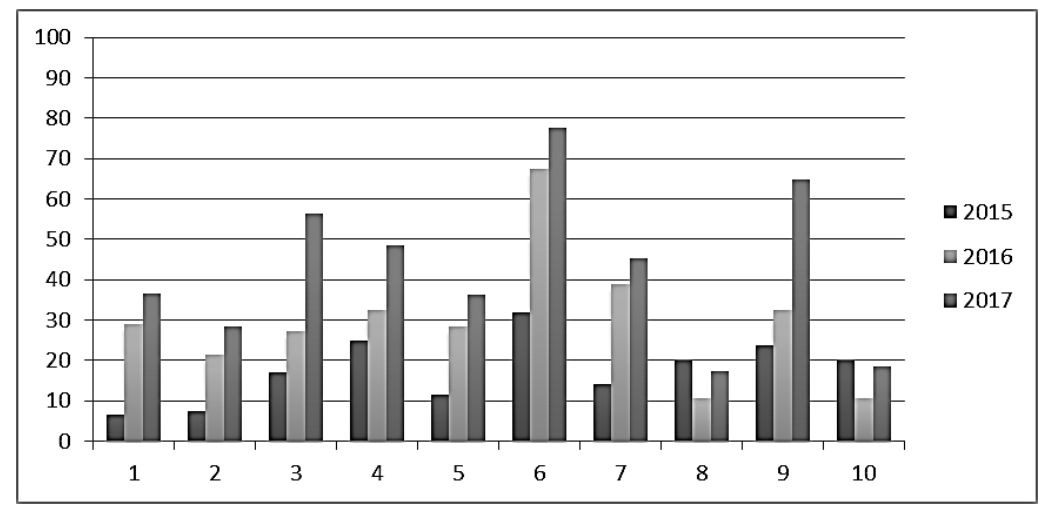

Рис. 3. Особливості психоемоційної сфери дітей 10-14 років.

Примітка: 1 - депресія, 2 - астенія, 3 -вегетативні розлади, 4 - порушення сну, 5- нейротизм, 6-агресія, 7 - страх війни, 8 - страх темряви, 9 - соџіальний страх, 10 - страх смерті

\section{2. Організація медико-психолого-педагогічної допомоги дітям}

Результати моніторингу психоемоційного стану дітей, які живуть за умов складної соціальної ситуації, встановили наявність емоційного напруження, психологічної та соціальної дезадаптації, нервовопсихічного зриву, зростання конфліктності та дестабілізації психоемоційного балансу особистості дитини загалом.

Слід відзначити, що запізніла або відсутня взагалі допомога накладає свій відбиток ще й на соматичне (фізичне) здоров'я дитини. Емоційні порушення можуть бути різного ступеня важкості та мати різні наслідки, отже, організація допомоги цим дітям повинна бути комплексною, здійснюватися єдиною командою фахівців і будуватися на інтегрованих засадах. Це поєднання співзвучне з багатовимірним процесом інтеграції. В освіті інтеграція нерозривно пов'язана 3 міждисциплінарністю в системі «педагог - психолог - батьки». Щодо зазначеної проблеми доцільним і важливим виступає врахування медичного лікувальнодіагностичного аспекту, тобто допомога дитині повинна відбуватися в інтегрованій системі «педагог - психолог - лікар - батьки».

Задля подолання несприятливих наслідків стресової ситуації та відновлення емоційно-вольової сфери дітей дієвою $є$ цілеспрямована комплексна допомога 3 тенденцією розробки спільних заходів між 
практичними психологами освіти, вихователями, лікарями та психологами охорони здоров'я, 3 обов'язковою участю батьків у цьому процесі. Організація роботи в такій системі дає можливість впливати та відновлювати соматичний, психічний і поведінковий рівні дитячого організму.

Комплексні заходи медико-психолого-педагогічної допомоги до вивчення проблем здоров'я дітей $\epsilon$ не тільки міждисциплінарними, ураховуючи індивідуальні характеристики, актуальний стан і поведінку кожної дитини, але мають й лонгітюдну дію впливу. Можливість отримання тривалої та стабільної підтримки через інтеграційне поєднання психології, педагогіки та медицини $є$ важливою запорукою ефективності відновлення психологічного стану дитини.

Ідея інтеграції втілюється у вигляді мультивимірного процесу з такими елементами, як-от:

- міждисциплінарна інтеграція, що полягає у тісній співпраці лікарів, педагогів, психологів та інших фахівців;

- інтеграція діагностично-терапевтичного та навчально-виховного процесів у дитячому садку, закладі охорони здоров'я та родині.

Професійний діалог, співпраця і взаєморозуміння - це та основа інтеграції, на якій будується взаємодія суб'єктів психологічнопедагогічної та медичної діяльності (рис. 4). Без цього неможливо досягти повноцінного успіху у здоровій соціалізації дітей та вирішенні наявних проблем.

Інтеграція запропонованої системи дає об'єднання загальних цілей, формування прихильності психолого-медико-педагогічної організації таким чином, щоб педагоги, психологи, лікарі та батьки максимально реалізували свій потенціал на загальне благо - зміцнення та відновлення психічного та соматичного здоров'я дітей.

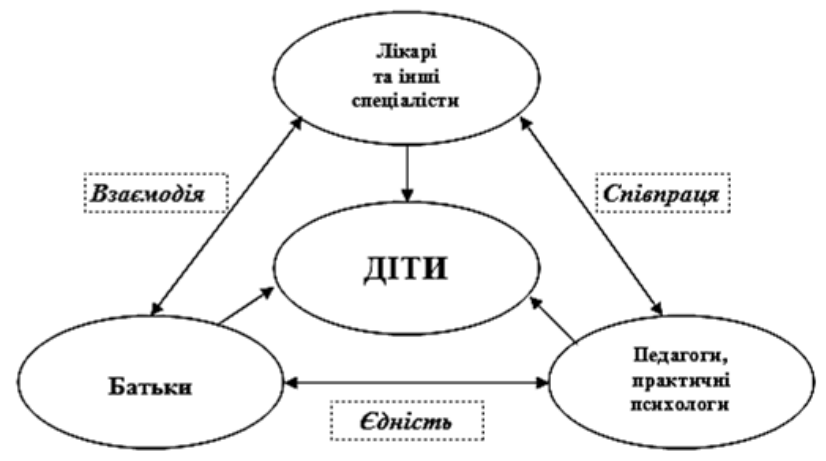

Рис. 4. Схема інтеграції системи «педагог - психолог - батьки - лікар» 
Інтеграція системи є одним із механізмів узгодження інтересів iї учасників і цілей менеджерів (керівників).

Цілі інтеграції:

- повноцінне, взаємоефективне співробітництво педагогів, практичних психологів, лікарів, дітей і батьків;

- створення сприятливих умов для повноцінного психологічного та соматичного становлення, виховання і навчання дітей;

- єднання, згуртовування учасників системи, установлення взаєморозуміння між батьками та дітьми, створення комфортних, сприятливих умов для розвитку дитини в дошкільному, шкільному, а надалі - в інших закладах освіти, а також у власній сім'ї.

Отже, успішна реалізація поставленої мети можлива за взаємодії педагогів, практичних психологів, лікарів і батьків. Останнє зумовлене такими обставинами:

- єдиним об'єктом (суб'єктом - дитиною);

- можливістю всебічного вивчення дитини та координації впливів на її розвиток (на рівнях закладу освіти, закладу охорони здоров'я);

- необхідністю узгодженості дій спеціалістів, фахівців і батьків;

- можливістю об'єднання зусиль педагогів, практичних психологів, лікарів і сім’ї у вирішенні проблем дитини;

- можливістю взаємного інтелектуального збагачення сімей, педагогічного колективу, кожного учасника взаємодії.

Вищим рівнем інтеграції педагогів, практичних психологів, лікарів і батьків є співпраця, яка характеризується такими показниками: взаємопізнанням, взаєморозумінням, сприятливими взаєминами, взаємовпливом.

Напрямами інтеграції виступають:

- створення сприятливої соціально-психологічної атмосфери;

- забезпечення необхідним психолого-педагогічним супроводом (у межах закладу освіти), медико-психологічною допомогою та реабілітацією (у межах закладу охорони здоров'я);

- позитивна соціалізація й адаптація дітей;

- духовно-моральний розвиток, удосконалення моральних якостей;

- надання допомоги та психологічної підтримки батькам у сімейному вихованні.

Результатом інтеграції стає результативність взаємодії усіх суб'єктів один з одним у спілкуванні та діяльності. Запорукою результату $\epsilon$ підхід 3 оптимістичною гіпотезою до кожної сім'ї, кожного з батьків, дитини щодо вирішення проблем, які виникають.

Значущість емоційного та психічного здоров'я дітей розуміють багато батьків, тому залучення їх до проблем дитини стає цілком природним. Залучати батьків до організації медико-психологопедагогічного процесу необхідно й тому, що дитина значну частину 
часу проводить у закладі освіти, тому сполучною ланкою між дитиною та батьками є педагог, який здійснює супровід взаємодії дитини та батьків. Це означає, що педагог вивчає стан взаємодії батьків і дітей у сім’і, визначає труднощі, проблеми взаємодії в сім'ях і підбирає адекватні засоби їхнього врегулювання. У роботі вихователя чи вчителя $є$ корисним виявлення, вивчення й узагальнення позитивного досвіду взаємодії дітей і батьків у сім'ї, поширення останнього серед інших батьків. Такі дії сприяють створенню особливої атмосфери для встановлення контактів при організації спільної діяльності.

У зв'язку з цим кожен фахівець своєї ланки психолого-медикопедагогічної системи бере на себе організацію конкретної роботи відповідно до своїх можливостей і кваліфікаційних засад.

Спільна діяльність підвищує якість допомоги, підживлює інтерес до кожної окремої ситуації, розвиває мотивацію та формує сприятливі взаємовідносини між фахівцями.

Різноманітна діяльність психолого-медико-педагогічної системи має більші можливості для розвитку відносин між педагогами, лікарями, батьками та дітьми завдяки системі переадресування. Ця система дозволяє не тільки здійснювати комплексний вплив на дитину, яка потребує допомоги, а й перенаправляти їі в разі необхідності посилення визначеного компоненту комплексної психолого-медико-педагогічної системи. Реалізація запропонованої психолого-медико-педагогічної системи відповідає певній етапності дій, але першочергово для здійснення вказаних дій важливо створити інформаційну базу дітей дошкільного віку, які зазнали або відчувають зараз вплив емоційного напруження.

Підготовчий етап: занесення даних про дитину до інформаційної бази. Виконавці: педагог, практичний психолог освітньої установи; батьки.

Завдання: аналіз первинної інформації про дитину 3 метою 3'ясування соціального статусу дитини.

1-й етап «Діагностичний».

Виконавці: педагог, практичний психолог освітньої установи, батьки.

Завдання: діагностика та виявлення психоемоційних проблем та індивідуальних особливостей дитини; формулювання психологопедагогічної проблеми.

2-й етап «Оцінно-планувальний».

Виконавці: практичний психолог освітньої установи, практичний психолог медичного закладу, лікарі, батьки.

Завдання: формування висновків і планування подальшої діяльності.

За результатами психологічного тестування формується робочий висновок, на основі якого може бути сплановано два варіанти подальшої роботи $з$ дитиною. 
Перший варіант передбачає роботу з дитиною, котра має тільки проблеми психологічного характеру і потребує поглибленої психологопедагогічної роботи. За цього варіанта психолого-педагогічним консиліумом закладу освіти розробляється план корекційнорозвивальних заходів і передбачених результатів роботи.

Другий варіант - переадресування - реалізується у разі психологічних проблем, виявлених у дитини із соматичними та психосоматичними порушеннями. Необхідним $є$ поглиблене медикопсихологічне обстеження в закладі охорони здоров'я і перенаправлення до фахівців. Завданням освітнього закладу є організація пояснювальної роботи з батьками щодо необхідності перенаправлення та поглибленого медико-психологічного обстеження дитини. Забезпечення системи перенаправлення та подальшої наступності 3 медичною установою надає можливості якісно обстежити здоров'я дитини (у т. ч. соматичне та психосоматичне).

Для цього використовують ресурс створення Карти клінікопсихологічного та соціального обстеження дитини ${ }^{8}$.

На основі поглибленого медико-психологічного огляду та проведених обстежень групою вказаних фахівців розробляється корекційно-відновлювальний маршрут комплексної роботи з дитиною в медичній установі.

3-й етап «Діяльнісно-комплексний».

Виконавці: практичний психолог освітньої установи, практичний психолог медичного закладу, лікарі, батьки.

Завдання: реалізація плану корекційно-розвивальних заходів (діяльнісний компонент) або корекційно-відновлювального маршруту (комплексний компонент).

Діяльнісно-комплексний етап може відбуватися за двома варіантами - діяльнісним і комплексним. Діяльнісний компонент здійснюється за умов закладу освіти та передбачає системний корекційно-розвивальний вплив на дитину і відстеження результатів. Комплексний компонент передбачає взаємодію закладів дошкільної освіти й охорони здоров'я, яка відбувається за технологією «Системне коло» (рис. 5). Безпосередня робота цього етапу передбачає реалізацію корекційновідновлювального маршруту за умов закладу охорони здоров'я, спрямованого на відновлення фізичного, психічного й соціального здоров’я дитини.

8 Кабанцева А.В., Корнєєва О.Л. Підтримка дитини в умовах емоційного напруження : навчально-методичний посібник. Київ : КВІЦ, 2018. 136 с. 


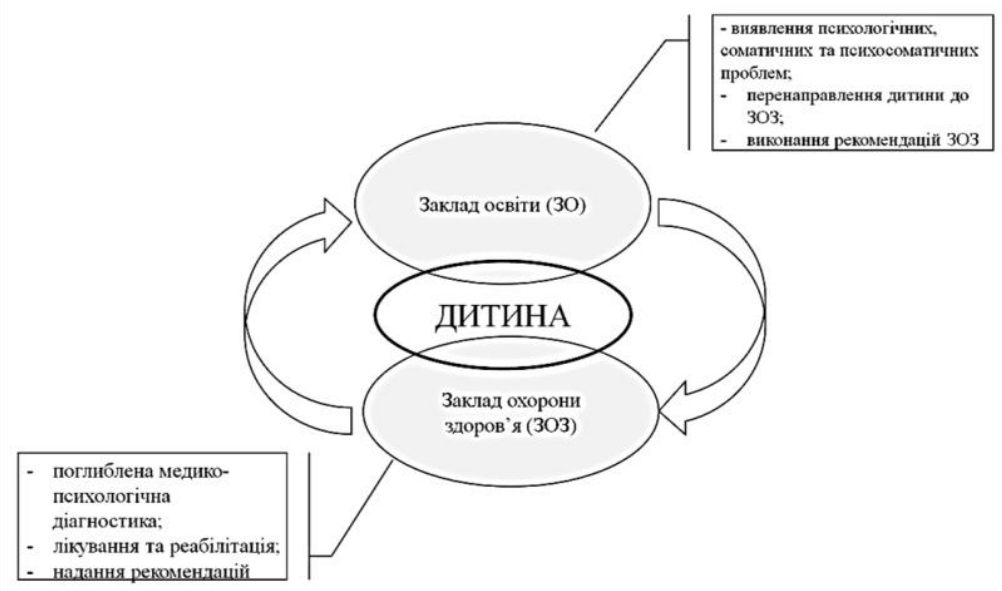

Рис. 5. Технологія «Системне коло»

Цей маршрут включає медикаментозне, фізіотерапевтичне лікування; психотерапевтичну, психокорекційну роботу з подальшою реабілітацією. Після завершення корекційно-відновлювального маршруту дитина продовжує реабілітацію в діяльнісному форматі за умов закладу освіти. У цьому полягає системність взаємодії закладів освіти й охорони здоров'я.

4-й етап «Підсумково-рекомендаційний».

Виконавці: вихователь, практичний психолог закладу освіти, лікарі, практичний психолог медичної установи.

Завдання: попередня оцінка дієвості корекційно-розвивальних заходів або корекційно-відновлювального маршруту; аналіз виконаної роботи, формування рекомендацій і подальшого супроводу дитини.

5-й етап «Рекреаційно-профілактичний».

Виконавці: працівники санаторно-оздоровчого закладу або закладу освіти із функціями оздоровчого.

Завдання: зміцнення ресурсного потенціалу дитини.

На цьому етапі дитина відвідує санаторно-оздоровчий заклад або в межах освітнього закладу проводиться робота щодо профілактики емоційної дестабілізації, зміцнення адаптаційних ресурсів, зміцнення психічного здоров'я, психологічного благополуччя.

Технологія медико-психолого-педагогічної допомоги дітям, котрі перебувають за умов соціально-психологічного напруження, включає в себе корекційно-розвивальні та корекційно-відновлювальні заходи, які інтегруються в роботу як медичних установ, так і закладів освіти. Інтеграційні процеси, що поєднують діяльність цих закладів, 
продиктовані часом і $\epsilon$ перспективними для здійснення якісної допомоги дітям. Вони грунтуються на взаємодії фахівців і спрямовані на посилення позитивних тенденцій налагодження спільної діяльності батьків, педагогів, психологів, лікарів у результативному подоланні проблем дитини.

\section{ВИСНОВКИ}

1. Нинішня соціально-економічна ситуація стає справжнім випробуванням для сучасних дітей і підлітків. Бойові дії мають тяжкі наслідки для фізичного i психічного здоров'я, а також для психологічного комфорту. Діти та підлітки, які мешкають у зоні збройного конфлікту, зазнають психотравматичного досвіду, що супроводжується наявністю тривоги, агресії, страхів війни, фізичних ушкоджень, соціальних страхів. Порушення психоемоційної сфери провокують розвиток невротичних проявів, таких як: порушення сну, невротизація, вегетативні порушення, емоційна лабільність.

2. У рамках виконання науково-дослідних робіт за запитом МО3 України доведено, що психологічному благополуччю і повноцінному розвитку дітей дошкільного віку перешкоджають страхи різного походження (полігамність страхів - 61,2\%), наявність тривожності, занепокоєності, хвилювання (53,2\%), прояви агресивності $(36,7 \%)$, низької самооцінки $(18,4 \%)$. Відповідно, серед підлітків актуальним виступає підвищення показників за соціально значущими шкалами («Соціальний страх» $\mathrm{i}$ «Страх фізичних ушкоджень»), що говорить про почуття небезпеки з боку соціуму. Також у цієї категорії дітей високі показники тривоги й агресії. Слід відзначити, що стан тривоги $\epsilon$ фундаментом для розвитку психосоматичних захворювань і призводить до загальної реакції з боку всього організму, формування стійкої зміни особистості. Поряд із цим достатньо велика кількість дитячих страхів $\epsilon$ наслідками батьківських страхів і об'єктизуванням форм базальної тривоги, а отже, роботу з дітьми потрібно планувати з урахуванням включення батьків у реабілітаційно-відновлювальний процес.

3. Оскільки діти мають різну глибину психотравматичного досвіду, наявні емоційні порушення мають широкий ступінь важкості та різноманітні наслідки. Організація допомоги цим дітям повинна бути диференційованою, але комплексною, здійснюватися єдиною командою фахівців і будуватися на інтегрованих засадах, а саме через колаборацію педагогів, психологів, лікарів у системі психологомедико-педагогічної допомоги. Використання системи переадресування і реалізація технології «Системне коло» уможливлює організацію своєчасної допомоги вузьких фахівців i включає корекційнорозвивальні та корекційно-відновлювальні заходи, які інтегруються в роботу як закладів освіти, так і медичних установ. Інтеграційні 
процеси, що поєднують діяльність цих закладів, продиктовані часом i $є$ перспективними для здійснення якісної допомоги дітям.

4. Запропонована система допомоги грунтується на взаємодії фахівців i спрямована на посилення позитивних тенденцій налагодження спільної діяльності батьків, педагогів, психологів, лікарів у результативному подоланні проблем дітей. Мультимодальність i етапність в організації медико-психолого-педагогічної допомоги дітям надає чіткості діям кожного суб’єкта цієї діяльності. Покладені в основу роботи принципи комплексності, системності та диференційованого підходу спрямовані на оптимізацію стану психічного здоров’я та покращення якості життя.

\section{АНОТАЦІЯ}

Сучасні діти живуть в епоху соціально-інформаційних викликів, що викликають зміни ритму життя і ріст постійного впливу стресових факторів на дитячу психіку. Представлені матеріали висвітлюють актуальні психологічні проблеми дітей Сходу України, їхні наслідки на психічному, психосоматичному i соматичному рівнях здоров'я. За результатами психодіагностики у дітей дошкільного віку встановлено страхи різного походження (полігамність страхів - 61,2\%), наявність тривожності, занепокоєності, хвилювання $(53,2 \%)$, прояви агресивності $(36,7 \%)$, низької самооцінки $(18,4 \%)$. Відповідно, серед підлітків актуальні підвищення показників за соціально значущими шкалами («Соціальний страх» $\mathrm{i}$ «Страх фізичних ушкоджень»), що говорить про почуття небезпеки з боку соціуму. Щодо встановлених порушень розроблено систему дієвої допомоги дітям через колаборацію дій психологів, лікарів, педагогів. Представлено авторську технологію «Системне коло», яка включає корекційно-розвивальні та корекційно-відновлювальні заходи, що інтегруються в діяльність як закладів освіти, так і медичних установ 3 урахуванням реалізації принципів комплексності, системності та диференційованого підходу. Запропонована система допомоги грунтується на взаємодії фахівців i спрямована на посилення позитивних тенденцій налагодження спільної діяльності батьків, педагогів, психологів, лікарів у результативному подоланні проблем, що існують у дітей. В основу роботи покладено принципи комплексності, системності та диференційованого підходу, спрямованих на оптимізацію стану психічного здоров'я та покращення якості життя.

\section{ЛІТЕРАТУРА}

1. Кузьмінов В.Н., Шестопалова Л.Ф. Розлади адаптації серед цивільного населення, що пережило бойові дії, через місяць після їхнього припинення. Український вісник психоневрологї. 2014. Т. 22. Вип. 3. С. 5-12. 
2. Больные души чеченских детей. URL: http://www.watchdog.cz/? show $=000000-000002-000001-000110-000045 \& l a n g=2$ (дата звернення: 08.12.2020).

3. Terr L.C. Childhood traumas: an outline and overview. American Journal of Psychiatry. 1991. 10-20. P. 148.

4. Венгер А.Л., Морозова Е.И. Психологическая помощь детям и подросткам после Бесланской трагедии. Владимир : Транзит-ИКС, 2009. $170 \mathrm{c}$.

5. Number of Ukrainian children needing aid nearly doubles to 1 million over the past year - UNICEF. URL: https://www.unicef.org/media/ media_94886.html (дата звернення: 27.09.2019).

6. Статус дитини, яка постраждала внаслідок воєнних дій та збройних конфліктів, на сьогодні мають понад 33 тисячі дітей. URL: https://www.ukrinform.ua/rubric-society/2791124-v-ukraini-ponad-33tisaci-ditej-maut-status-postrazdalih-unaslidok-voennih-dij.html (дата звернення: 6.12.2020).

7. Проблеми розвитку та корекції емоційної сфери молодшого школяра / упоряд. О.А. Атимасова. Харків : Вид-во «Ранок», 2010. 176 с.

8. Кабанцева А.В., Корнєєва О.Л. Підтримка дитини в умовах емоційного напруження : навчально-методичний посібник. Київ : КВІЦ, 2018. 136 с.

\section{Information about the authors:}

Panchenko O. A.,

Doctor of Medicine, Honored Doctor of Ukraine, Chief Researcher, Professor at the Department of Medical Informatics, Member President All-Ukrainian Professional Psychiatric League 26, Petra Zaporozhtsia str., Kyiv, 02125, Ukraine, Director

Scientific and Practical Medical Rehabilitation and Diagnostic Center of the Ministry of Health of Ukraine 14, Nevskoho str., Konstantinovka, Donetsk region, 85110, Ukraine

Kabantseva A. V., Ph.D. of Psychology, Associate Professor at the Department of Psychology Donetsk National Medical University 27, Pryvokzalna str., Liman, Donetsk region, 84404, Ukraine 